\title{
DEBATOPL/EG III
}

\section{BEBOR MANGFOLDIGE VERDENER}

\author{
For udsagnet
}

\section{MORTEN AXEL PEDERSEN}

\section{Kaere publikum, cerede opponenter}

Jeg vil gerne indlede med at slå fast med syvtommersøm, at det at plædere for, at mennesker bebor mangfoldige verdener, ikke er det samme som at plædere for eksistensen af forskellige kulturer med veldefinerede geografiske, sociologiske eller epistemologiske afgrænsninger. Plurale verdener er ikke det samme som plurale kulturer. Jeg anerkender, at man kan (mis)forstå den teoretiske position, som vi forsvarer, på denne måde, og at mange antropologer har forstået den sådan, inklusive en del, som siges at repræsentere den såkaldte „ontologiske vending“ $\mathrm{i}$ antropologien. Men det begreb om mangfoldige verdener, som jeg argumenterer for her, er ikke stedsbestemt, ligesom det heller ikke refererer til bestemte sociale grupper eller individer, der hver især bebor deres egen verden. At sige, at vi bebor mangfoldige verdener, er således hverken et kulturalistisk eller et solipsistisk udsagn: En sandsigerske i Mozambique og en postmand på Fyn bebor ikke nødvendigvis verdener, der er mere forskellige end dem, Morten Nielsen og Morten Axel Pedersen og for den sags skyld Kirsten Hastrup og Christian K. Højbjerg færdes i.

Derfor kan den teoretiske position, jeg ønsker at forsvare her, ikke indfanges med udsagnet, „vi lever på forskellige måder i den samme verden“ (jf. plakaten for dagens arrangement). Dette ville netop udgøre en art modificeret kulturalisme, der forsøger at tage de seneste par årtiers kritik af det klassiske kulturbegreb til indtægt ved at gøre folks betydningsuniverser mere dynamiske, individualiserede og heterogene. Ifølge denne opfattelse af dagens udsagn - som måske ikke ligger milevidt fra vores to ærede opponenters? - findes der en verden „derude“, som mennesker til forskellige tider og på forskellige tidspunkter så „opfatter“ og „italesætter" forskelligt, alt afhængigt af hvilke „epistemologiske briller“ de har på. Det antropologiske projekt bliver her at studere de kategorier og meninger, 
som mennesket, via en altid politiseret og dermed ulige betydningsproduktion, tillægger en ydre virkelighed, hvis væsen i bedste kantianske tradition anskues som uden for menneskelig rækkevidde og begribelse.

Før jeg vender blikket nærmere mod den antagelse, der ligger til grund for den teoretiske position, som jeg forsvarer i dag, så vil jeg gerne påpege, at den gængse antropologiske konvention - ,at vi lever på forskellige måder i den samme verden“ - har præcis lige så mange „metafysiske“ implikationer som den såkaldte „ontologiske vending“ $i$ antropologien, som mange vil opfatte Morten og mig som repræsentanter for (se fx Viveiros de Castro 1998; Henare et al. 2007b; Jensen et al. 2011). At påstå, at mennesker bebor den samme verden (som de så opfatter mere eller mindre indbyrdes forskelligt), er akkurat lige så ,spekulativt“", „filosofisk“ og „ontologisk“" som at sige, at vi bebor mangfoldige verdener. Det er af samme grund udtryk for et falsk valg, hvis man tror, at antropologien kan „nøjes“ med at stille ,epistemologiske“ spørgsmål angående, hvordan mennesker opfatter, skaber viden om og på denne baggrund agerer i verden, og så overlade de mere „ontologiske“ spørgsmål angående verdens beskaffenhed til filosofien og naturvidenskaben (Pedersen 2012a). Antropologiske spørgsmål er altid ontologiske (og i øvrigt altid epistemologiske) spørgsmål, uagtet om man vil det eller ej, og om denne metafysiske dimension er eksplicit eller ej. Hvad vi debatterer i dag, må derfor ses som to forskellige teorier om, hvad verdens beskaffenhed er - og dermed også to forskellige teorier om, hvori mennesket og det videnskabelige studie af mennesket består.

Så hvad vil det sige, at vi bebor mangfoldige verdener? Et muligt svar er at vende den gængse antagelse om, at mennesker bebor en fælles verden forskelligt, på hovedet. I stedet for at sige, at ,vi lever på forskellige måder i samme verden“, kunne man så ikke forestille sig det omvendte - at ,vi lever på samme måde i forskellige verdener"? Dette er grundlæggende, hvad jeg ser det som vores ærinde at forsvare i dag: antagelsen om multiple verdener, som det er menneskets lod konstant at bevæge sig ind og ud af, helt på linje i øvrigt med alle andre livsformer. Bemærk forskellen fra den kulturalistiske eller solipsistiske position, der, som tidligere nævnt, også opererer med en idé om multiple verdener, men bygger på den af flere grunde (i epistemologisk, politisk og etisk forstand) problematiske antagelse, at denne pluralitet udtrykker de mere eller mindre inkommensurable (og underforstået, mere eller mindre sande) måder, hvormed mangfoldige kulturer repræsenterer en virkelig virkelighed. Dette adskiller sig radikalt fra den „naturrelativistiske“ eller „,ikke-repræsentionelle“ idé om mangfoldige verdener, jeg (og Morten) plæderer for, hvor der akkurat ikke eksisterer en fælles verden, men mange forskellige verdener „,derude“, som alle mennesker (og andre livsformer) bebor på samme måde. Det var derfor, jeg tidligere kunne hævde, at den 
mozambiquiske heksedoktors virkelighed ikke nødvendigvis er mere anderledes end postmandens på Fyn, end min virkelighed er i forhold til Morten Nielsens. For inden for rammerne af den teoretiske position, jeg her forsvarer, handler det principielt ikke om forskellige steder (Mozambique og Danmark) eller for den sags skyld forskellige mennesker (Morten og hans veninde heksedoktoren). Det handler om de uendeligt mangfoldige mulige og umulige verdener, som er virkeligheden, og på tværs af hvilke, vi ubønhørligt bliver forskudt og lader os forskyde som en slags laterale astronauter, der altid står på tærsklen af nye universer i alle retninger.

Nogle ville indvende, at det er rendyrket sofisteri at omtale virkeligheden som mangfoldig i sit væsen, for hvordan tale om et „væsen“, der ikke er én, men alle tænkelige og utænkelige værensformer? Prøv bare at overveje, hvilke radikale implikationer dette har for videnskabelig praksis, ville mange advare: Hvis virkeligheden antages at være multipel af natur, hvordan så opnå viden om, for ikke at sige generalisere over, dens beskaffenhed? Er den såkaldt ontologiske vending ikke blot et skalkeskjul for en fortsættelse af den postmoderne fetichering af det partikulære og det subjektive - en updated deleuziansk/latouriansk udgave af anything goes? For ikke at nævne den negative effekt, dette teoretiske perspektiv synes at have på det kritiske potentiale, som samfundsvidenskaben, og ikke mindst antropologien, betragter som en af sine mest skattede egenskaber: Hvordan agere som epistemologisk vagthund i samfundet, hvis særlige rolle det er at afessentialisere alt, hvad der fremstår som naturligt, når vi konstant hopper rundt mellem multiple øer af radikal-essentialistisk væren? Lad mig nu med henblik på at imødekomme disse mulige indvendinger fremhæve tre væsentlige teoretisk-metodiske implikationer, som udsagnet ,vi bebor mangfoldige verdener“ afføder.

\section{Relationer er ulig forbindelser}

Hvis virkelighedens væsen antages at være multipel, og hvis den menneskelige tilværelse (på linje med andre livsformer) siges at bestå i en evig forskyden mellem disse mange verdener, indebærer det nødvendigvis et opgør med den gængse idé om, hvad relationer er. Snarere end at betragte relationer som forbindelser mellem to adskilte punkter, hvilket synes at være den konventionelle opfattelse blandt antropologer og sociologer, udvides relationsbegrebet her til at omfatte enhver type forhold mellem to givne verdener, inklusive disses eventuelle ønske om maksimal adskillelse igennem løbende antagonisme og strid. Relationer er i den forstand intensive snarere end ekstensive, for at låne et ord fra Bergson - „, forbindelser“, ,,adskillelser“" og „,konflikter“ bliver her produkter af snarere end 
forudsætninger for relationer, der opfattes som en art grundsubstans, hvorigennem multiple verdener udstanses (Pedersen 2012b). Et godt eksempel er antropologiske studier af slægtskab i forskellige (især, men ikke udelukkende ikke-vestlige) sammenhænge, der viser, at det at være relateret ses som et udgangspunkt snarere end et udkomme af socialt liv - og hvor forbindelser mellem slægtninge snarere udgør en problemstilling, der skal reduceres, end et moralsk ideal, der bør opfyldes (Wagner 1977; Strathern 1988).

Et ofte anvendt billede på denne radikalt relationelle eller intensive virkelighed, hvor alting er indfoldet $i$ hinanden, og hvor ingenting udgør en autonom og afgrænset genstand, er de russiske matrjosjkadukker (Gell 1998; Wagner 1991). For dette er netop, hvad virkeligheden består af i et radikalt relationelt perspektiv: en uendelig perlerække af verdener (i slægtskabsmæssige sammenhænge, forskellige slægtninge), som alle sammen potentielt kan indeholdes i hinanden, som om det mangefold af kloder, der udsmykker dagens plakat, var indeholdt i hinanden, matrjosjkaagtigt. Dette har den paradoksale konsekvens, at ethvert fænomen, der synes at udgøre en enhed, samtidig dækker over en flerhed, og vice versa (Deleuze \& Guattari 1999; Strathern 2004; Pedersen 2011b:115-47). I den forstand ville en mere præcis udlægning af den position, som jeg forsvarer her i dag, være at sige, at vi bebor en multipel virkelighed, der hele tiden udkrystalliserer sig og transmuterer sig i form af et mangefold af verdener.

\section{Ikke-skeptisk kritik}

Det bringer mig tilbage til det tidligere rejste spørgsmål om antropologiens kritiske potentiale og om, hvorvidt fagets selvbestaltede rolle som epistemologisk vagthund ikke står for fald inden for rammerne af det teoretiske perspektiv, som det er min rolle at forsvare her i dag. For der skal ikke herske nogen tvivl om, at den selvrefleksive dekonstruktion, som mange opfatter som selve kernen i den moderne antropologiske kritik, ikke giver den store mening i en multipel virkelighed bestående af et intensivt mangefold af indbyrdes indfoldede verdener. Men hermed ikke være sagt, at der ikke er mulighed for et kritisk antropologisk projekt inden for sidstnævnte perspektiv. Formuleret lidt firkantet (hvilket vel er meningen i en debat som denne?) indeholder antropologien to modsatrettede potentialer for kritisk intervention, som kan forbindes med hver af de to teoretiske positioner, vi debatterer i dag. For det første har vi, hvad man kunne kalde, den skeptiske kritik, hvis bærende princip er af-essentialisering: At kritisere antropologisk handler her grundlæggende om at vise, at det, som tages for givet, alligevel ikke er så givet, når det kommer til stykket - at vise, at det, der virker virkeligt, i virkeligheden ikke er så virkeligt, og at det, der fremstår som essens, alligevel 
ikke er så essentialistisk - inden for rammerne af den fælles verden, som vi alle antages at bebo, vel at mærke. Den anden type antropologisk kritik, som man kunne kalde ikke-skeptisk (i mangel af bedre - jeg nægter at kalde den ,positiv“ eller ,glad“!), er på mange måder defineret ved det præcis omvendte. Som en udbygning af, hvad Henare et al. (2007b) har kaldt, „metodologisk naivisme“, består denne type antropologisk kritik således $\mathrm{i}$ at tage tingene mere alvorligt, end alle andre gør (selv „folk selv"); i at gøre det, der fremstår som virkeligt, endnu mere virkeligt (eller snarere, i at gøre det virkeligt på flere måder); og i at reagere på essentialisme ved selv at voere mere essentialistisk - alt sammen inden for rammerne af de mangfoldige verdener, vi alle siges at bebo.

Man kan diskutere, hvorvidt et sådant forehavende overhovedet kan betegnes som kritik, men for mig hersker der ingen tvivl. Hvis vi definerer den akademiske kritik som installeringen af potentialet for en ønskværdig forskydning af virkeligheden via en bestemt konceptuel intervention, kan dette kriterium i lige så høj (hvis ikke højere) grad opfyldes via ikke-skeptisk metodologisk naivisme som via skeptisk refleksiv dekonstruktion. Men er dette ikke en farlig sti at bevæge sig ned ad - hvordan laver man eksempelvis en radikalt essentialistisk kritik af højrenationale bevægelser? Hvordan kan man - for nu at tage det mest ekstreme eksempel - som etnograf tage, hvad en gruppe neofascistiske informanter siger, ikke bare alvorligt, men endnu mere alvorligt, end de selv gør? Mit svar på dette potentielt sprængfarlige spørgsmål er lige så enkelt, som det givetvis er svært at gennemføre i praksis. For det er her afgørende at huske på, at den radikalt essentialistiske intervention indebærer akkurat lige så meget forvrængning af informanternes virkelighed, som en mere konventionel skeptisk dekonstruktion gør. Som Morten også var inde på i sit oplæg, handler det antropologiske projekt, som vi forsvarer her i dag, grundlæggende om skabelsen af nye begreber med udgangspunkt i de begreber, som vi indsamler via vores etnografiske arbejde. At være for udsagnet ,vi bebor mangfoldige verdener“ handler således ikke om at go native, men om kreativt at bearbejde de begreber, man har indsamlet i felten, med en respekt for den konceptuelle modstand, de udøver, og ydmyghed over for den iboende skaberkraft, de indeholder, lidt som en billedhugger gør med et stykke granit (Deleuze \& Guattari 1994; Holbraad \& Pedersen 2009). Af samme grund ville en ikke-skeptisk kritik af en højrenational bevægelse aldrig bestå i en - i ,tolerancens" misforståede navn - pervers eftersnakken af deres ekstremistiske udgydelser. Det, som den radikalt essentialistiske antropologiske kritiker derimod ville gøre, var at forsøge at destabilisere det begrebsmæssige grundlag for denne (og andre) ekstremistiske essentialismer. Blot ville denne destabilisering ikke bestå i en undergravende dekonstruktion af disse begreber, men snarere i en slags strategisk ,tilhugning“ af dem med henblik på at få dem til irreversibelt at „overflyde“ deres eget grundlag og dermed implikation. 


\section{Posthumanistisk antropologi}

Med disse overvejelser er jeg landet ved den sidste overordnede implikation, som dagens udsagn efter min overbevisning har for det antropologiske projekt, nemlig spørgsmålet om, hvad genstanden for den antropologiske videnskab er. Mange ville mene, at svaret giver sig selv: Antropologi handler om studiet af mennesket, det ligger ligesom i ordets betydning. Her har vi nok en af grundene til, hvorfor mange antropologer vægrer sig ved, hvis ikke irriteres kraftigt af, al den snak om såkaldt „ontologisk vending“" og en ,symmetrisk antropologi“, der ønsker at „tage tingene seriøst" (som om man ikke har gjort det hele tiden!), og som antager, at også objekter kan have agens. Men for mig er problematikken omvendt: Vi kan ikke som antropologer nå videre angående spørgsmålet om, hvad mennesket er, så længe vi på forhånd mener at kende det menneskeliges afgræsning. Af samme grund kan påberåbelsen af et humanistisk antropologisk perspektiv paradoksalt nok ende op med at fungere som spændetrøje, i den forstand at humanismen indeholder en række mere eller mindre implicitte antagelser, teorier, ja, lad os bare sige det, ontologier, om menneskets beskaffenhed. Humanisme er en antropologi (teori om mennesket), men vel ikke den eneste? For mig at se er der brug for en anden antropologi, der ikke er så fastlåst i, hvori menneskets væsen består: en mindre skråsikker teoretisering af, hvad et menneske er, eller rettere, kunne være (Pedersen 2012a, 2012b).

Det er netop en sådan ,posthumanistisk antropologi“, som jeg mener, at dagens udsagn åbner op for. Spørgsmålet om menneskets „,natur“ er jo et åbent etnografisk spørgsmål, ja, det kan vel nærmest beskrives som det etnografiske spørgsmål over dem alle. Men netop derfor mener jeg, at det kan være problematisk at spørge alt for direkte ind til det. Ja, jeg ville hævde, at det præcis er med henblik på at tvinge spørgsmålet om mennesket til at forblive åbent, at jeg og andre ligesindede er så forhippede på at analysere ,ting“ som agenter og på at teoretisere om multiple verdener. Kun ved at undersøge og teoretisere, hvordan tilsyneladende ikke-menneskelige fænomener via snørklede begrebsmæssige veje kan konceptualiseres som menneskelige, kan det videnskabelige studie af mennesket forblive empirisk. At være for mangfoldige verdener er antropologens forsøg på at forblive ydmyg over for sin genstand. 